\title{
Antimicrobial Activity of Alcoholic Extracts of Medicinal Plants against Phytopathogenic Fungi
}

\author{
Clenilda Tolentino Bento da Silva ${ }^{1}$, Alessandra Keiko Nakasone ${ }^{1^{*}}$, \\ Walkymário de Paulo Lemos ${ }^{2}$, Osmar Alves Lameira ${ }^{3}$ \\ and Luana Cardoso de Oliveira ${ }^{4}$ \\ ${ }^{1}$ Plant Pathology Laboratory, Embrapa Eastern Amazon, Belém, Pará, Brazil. \\ ${ }^{2}$ Entomology Laboratory, Embrapa Eastern Amazon, Belém, Pará, Brazil. \\ ${ }^{3}$ Plant Biotechnology Laboratory, Embrapa Eastern Amazon, Belém, Pará, Brazil. \\ ${ }^{4}$ Institute of Exact and Natural Sciences, Federal University of Pará, Belém, Pará, Brazil.
}

Authors' contributions

This work was carried out in collaboration among all authors. Author CTBS designed the study, performed the statistical analysis, wrote the protocol and wrote the first draft of the manuscript. Authors AKN, WPL and LCO discussed the results and corrected of the manuscript. Author OAL gave away the medicinal plants used in the study. All authors read and approved the final manuscript.

Article Information

DOI: 10.9734/JEAI/2019/v41i630438 Editor(s):

(1) Dr. Ismail Seven, Assistant Professor, Department of Plantal and Animal Production, Vocation School of Sivrice, University of Firat, Turkey. Reviewers:

(1) Kawtar Fikri Benbrahim, Sidi Mohamed Ben Abdellah University, Morocco (2) Cristiane Ramos Vieira, Cuiabá University, Brazil. Complete Peer review History: http://www.sdiarticle4.com/review-history/53424

\section{ABSTRACT}

Aims: This work aimed to evaluate the antimicrobial effects of 14 alcoholic extracts of medicinal plants on the mycelial growth of Colletotrichum gloeosporioides, Fusarium oxysporum f. $\mathrm{sp}$. passiflorae, Fusarium solani and Rhizoctonia solani. Those are fungi that cause diseases in Passiflora edulis.

Study Design: With the obtained data the mycelial growth rate index (MGRI) was calculated, afterwards the analysis of variance was performed and the means were compared by the ScottKnott test at $5 \%$ probability.

Place and Duration of Study: Plant Pathology Laboratory, Embrapa Eastern Amazon, Belém, Pará, Brazil, between May 2014 and April 2015. 
Methodology: The extracts were prepared with $1.0 \mathrm{~g}$ of powdered plant material and $10 \mathrm{~mL}$ of commercial ethyl alcohol $92.8^{\circ}\left(0.1 \mathrm{~g} \mathrm{~mL}^{-1}\right)$ under constant agitation in an orbital shaker at $200 \mathrm{rpm}$ for 20 minutes. They were then kept in the refrigerator for 24 hours at rest. The extracts were centrifuged and filtered on Millipore membranes with $0.22 \mu \mathrm{m}$ porosity. The tests with the phytopathogenic fungi were carried out in vitro with the alcoholic extracts at $1 \%$ concentration. The experimental design was completely randomized with 15 treatments and 5 replicates.

Results: All the extracts reduced the growth of the fungi $C$. gloeosporioides. The extracts the Eucalyptus angulosa, Lippia alba, Zingiber officinale, Cymbopagon citratus, Azadirachta indica, Plectranthus barbathus, Hibiscus sabdariffa, Aloe vera, Pedilanthus tithymaloides, Mansoa alliacea and Chenopodium ambrosioides reduced the mycelial growth of $F$. oxysporum f. sp. passiflorae. Only the extract of $E$. angulosa presented reduction in the growth of $F$. solani. Meanwhile the extracts of $E$. angulosa, Z. officinale, L. alba, M. alliacea and $P$. barbathus reduced the mycelial growth of $R$. solani.

Conclusion: All extracts presented antimicrobial potential, being that the extract of E. angulosa reduced the mycelial growth of all the evaluated fungi.

Keywords: Antifungal activity; alternative control; medicinal plants; phytopathogenic fungi.

\section{INTRODUCTION}

In the state of Pará, the species Passiflora edulis Sims, popularly known as passionfruit, is one of the most important crops. Almost all commercial orchards are represented by Passiflora edulis Sims f. flavicarpa Deg. (yellow passionfruit). This species is appreciated for its characteristic taste and aroma. However, it is susceptible to various diseases that may compromise productivity and fruit quality and cause plant death [1].

Anthracnose, caused by Colletotrichum gloeosporioides, is widespread in all regions of $P$. edulis cultivation in Brazil and in other countries [2]. This pathogen has a wide range of hosts. Its symptoms can be observed in all organs of shoots, such as branches, tendrils, leaves, flower buds, and fruits [3].

The fungus Fusarium oxysporum f. sp. passiflorae W.L. Gordon (FOP) is specific to the Passifloraceae family. Responsible for fusariosis, this fungus colonizes plant vessels by causing small wounds or natural openings in roots, causing xylem obstruction and plant death [4]. The fungus $F$. solani is polyphagous and affects a large number of plant species, such as Nicotiana tabacum L., Phaseolus vulgares L., Solanum tuberosum L., Beta vulgaris L., and Capsicum annuum L. [2]. Unlike F. oxysporum f. sp. passiflorae, $F$. solani has no systemic action. The symptoms of the resulting plant base rot are characterized by rot and plant death due to root and plant base tissues rotting [5].

In Pará, the fungus Rhizoctonia solani affects several crops of economic importance, among them $P$. edulis [6]. In plants of this culture, the occurrence of leaf burn caused by the fungus is noticed by the necrosis in leaves with a yellow halo, which results in withering and fall of the leaves at the final stage of the disease [5].

There is currently a demand for sustainable alternatives to control diseases of various crops, especially in small and medium-sized plantation areas, using active ingredients that do not harm the environment, biodiversity and above all the health of farmers and consumers [7]. In this context, natural plant products may have an antimicrobial activity, because, act directly on the pathogen [8]. Thus, the alternative control is a great option to minimize the harmful effects caused by the intensive use of pesticides as sustainable agriculture prioritizes the use of natural products for the control of plant diseases [9].

This research aimed to evaluate the antimicrobial effects of 14 alcoholic extracts of medicinal plants on the mycelial growth of $C$. gloeosporioides, $F$. oxysporum f. sp. passiflorae, $F$. solani and $R$. solani, fungi that causes diseases in $P$. edulis.

\section{MATERIALS AND METHODS}

Samples of 14 medicinal plants were collected at the Embrapa Eastern Amazon medicinal plant garden. They were packed in plastic bags and taken to the Plant Pathology Laboratory. All species used in this research were identified by the Botanical Laboratory of Embrapa Eastern Amazon by the researcher MSc. Silvane Tavares Rodrigues. The herbarium specimens were 
deposited at the IAN Herbarium of the Institution. The species were Aloe vera (L) Burm. f. (aloe), Azadirachta indica A. Juss (neem), Chenopodium ambrosioides L. (wormseed), Cymbopogon citratus (D.C.) Stapf. (lemon grass), Eucalyptus angulosa Schauer. (eucalyptus), Hibiscus sabdariffa L. (roselle), Lippia alba (Mill) N.E. Brown (bushy matgrass), Mansoa alliacea (Lam.) A.H. Gentry. (garlic vine), Morinda citrifolia L. (noni), Ocimum basilicum L. (basil), Ocimum gratissimum L. (clove basil), Plectranthus barbatus Andrews (forskohlii), Pedilanthus tithymaloides Poit. (coramine) and Zingiber officinale Roscoe (ginger).

\subsection{Obtaining Alcoholic Extracts}

To obtain alcoholic extracts, only the leaves of the medicinal plants were used. The asepsis of the samples was performed by washing under running water, soaking in $70 \%$ alcohol for one minute and in $\mathrm{NaClO} 1 \%$ solution for two minutes. Then, the residual chlorine was removed using sterile distilled water. After removing excess water from the absorbent paper, the material was dried in a forced air oven (Quimis brand, Q.360.14) at $40^{\circ} \mathrm{C}$ until constant weight, and ground in an electric mill (Tecnal brand, Willye, TE 650) to obtain a powder [10]. The extracts were prepared with $1.0 \mathrm{~g}$ of the powdered material and $10 \mathrm{~mL}$ of $92.8^{\circ}$ commercial ethyl alcohol $\left(0.1 \mathrm{~g} \mathrm{~mL}^{-1}\right)$, and kept under constant agitation in an orbital shaker (Solab, SL223) at $200 \mathrm{rpm}$ for 20 minutes. They were then transferred to a refrigerator, and kept at rest for 24 hours. Subsequently, the extracts were centrifuged in a centrifuge (Eppendorf, Centrifuge $5430 \mathrm{R}$ ) at $7,000 \mathrm{rpm}$ for ten minutes at $4^{\circ} \mathrm{C}$, and filtered on Millipore ${ }^{\circledR}$ membranes with $0.22 \mu \mathrm{m}$ porosity, which were used soon after obtaining them [11].

\subsection{Origin of Pathogens}

The isolates of C. gloeosporioides, F. oxysporum f. sp. passiflorae, $F$. solani and $R$. solani were obtained from passion fruit plants showing characteristic disease symptoms at the municipalities of Castanhal, Parauapebas, Belém and Tomé-Açu (Pará, Brazil), respectively. They were preserved in mineral oil at the Plant Pathology Laboratory of Embrapa Eastern Amazon. For experimental use, the isolates were grown in potato dextrose agar (PDA) culture medium, and incubated for seven days at $28^{\circ} \mathrm{C}$.

\subsection{In vitro Tests}

To evaluate the in vitro antimicrobial activity, the alcoholic extracts were incorporated into the fluxing PDA culture medium, reaching a concentration of $1 \%$. After solidification of the culture medium containing the treatments, an 8$\mathrm{mm}$ diameter disc of mycelium was deposited at the center of each Petri dish. In control plates, the culture medium without the extracts was used. Mycelial growth was evaluated daily using a digital caliper until the fungus in one of the treatments reached the borders of the plate. The experimental design was completely randomized with 15 treatments and five replications. The obtained values were used to calculate the mycelial growth rate index (MGRI) [12]. An analysis of variance was performed, and the means were compared by Scott-Knott test [13] at $5 \%$ probability.

\section{RESULTS AND DISCUSSION}

In the assay with the fungus $C$. gloeosporioides, all extracts reduced the mycelial growth of the pathogen, differing from the control (Table 1). The extracts showed inhibitions between 11.73 and $50.66 \%$, and the extract of E. angulosa showed the best result, with an inhibition above $50 \%$ of C. gloeosporioides growth.

In the evaluation of the effects of extracts on $F$. oxysporum f. sp. passiflorae, the extracts of $E$. angulosa, L. alba, Z. officinale, Cymbopagon citratus, $A$. indica, $P$. barbathus, $H$. sabdariffa, $A$. vera, $P$. tithymaloides, $M$. alliacea and $C$. ambrosioides promoted a reduction in mycelial growth, differing from the control, with inhibitions between 5.28 and $51.73 \%$ (Table 2). As for the C. gloeosporioides assay, the best result was obtained by the extract of $E$. angulosa, which inhibited pathogen growth by $51.73 \%$.

In the evaluation of the effects of extracts on $F$. solani, only the $E$. angulosa extract was positive, differing from the control, with a $21.06 \%$ inhibition of pathogen mycelial growth (Table 3). All other extracts showed no antifungal activity. The extracts of $A$. indica, $M$. citrifolia, $C$. ambrosioides, O. gratissimum, M. alliacea, $P$. barbathus and $O$. basilicum stimulated the growth of $F$. solani.

In the antifungal assay on $R$. solani, extracts of E. angulosa, Z. officinale, L. alba, $M$. alliacea and $P$. barbathus decreased the fungal mycelial growth, differing from the control, with inhibitions between 5.15 and $28.68 \%$ (Table 4 ). All other 
extracts showed no antifungal activity, and stimulated pathogen growth.

In this study, the antimicrobial potential of the alcoholic extracts of studied medicinal plants was evident, with emphasis on the extract of $E$. angulosa, which promoted the inhibition of mycelial growth of all fungi tested.

No studies were found demonstrating the antifungal activity of $E$. angulosa extracts. However, Hedge, et al. [14] reported inferior results. The extract of Eucalyptus $\mathrm{sp}$. at the concentrations 5 and $10 \%$ reduced by 27.07 and $38.70 \%$, respectively, the mycelial growth of $C$. gloeosporioides. Koma, et al. [15] reported that the extract of Eucalyptus sp. completely inhibited the growth of $R$. solani.

The major classes of secondary metabolites isolated from different species of the genus Eucalyptus include floroglucinols, flavonoids and their glycosides, terpenes (monoterpenes, sesquiterpenes, triterpenes) and their glycosides, phenolics and their superior glycosides, steroids, tannins and polyphenols [16]. Thus, the antifungal activity of $E$. angulosa alcohol extract may be due to the presence of one or more compounds of these chemical classes. The antifungal activity of phenolic compounds of plants of the genus Eucalyptus, for example, was demonstrated by $\mathrm{Oh}$, et al. that isolated

Table 1. Effect of alcoholic extracts of medicinal plants on mycelial growth of Colletotrichum gloeosporioides

\begin{tabular}{|c|c|c|}
\hline Treatments & MGRI & Inhibition (\%) \\
\hline Eucalyptus angulosa & $13.03 c^{*}$ & 50.66 \\
\hline Ocimum basilicum & $19.93 b$ & 24.53 \\
\hline Zingiber officinale & $20.08 \mathrm{~b}$ & 23.96 \\
\hline Lippia alba & $21.02 \mathrm{~b}$ & 20.40 \\
\hline Azadirachta indica & $21.30 \mathrm{~b}$ & 19.35 \\
\hline Ocimum gratissimum & $21.49 \mathrm{~b}$ & 18.62 \\
\hline Plectranthus barbathus & $21.54 b$ & 18.43 \\
\hline Aloe vera & $22.07 b$ & 16.43 \\
\hline Cymbopagon citratus & $22.22 \mathrm{~b}$ & 15.86 \\
\hline Chenopodium ambrosioides & $22.35 \mathrm{~b}$ & 15.37 \\
\hline Mansoa alliacea & $22.45 b$ & 14.99 \\
\hline Morinda citrifolia & $22.52 b$ & 14.72 \\
\hline Pedilanthus tithymaloides & $22.61 \mathrm{~b}$ & 14.39 \\
\hline Hibiscus sabdariffa & $23.31 \mathrm{~b}$ & 11.73 \\
\hline Control & $26.41 \mathrm{a}$ & - \\
\hline
\end{tabular}

Table 2. Effect of alcoholic extracts of medicinal plants on mycelial growth of Fusarium oxysporum f. sp. passiflorae

\begin{tabular}{lll}
\hline Treatments & MGRI & Inhibition (\%) \\
\hline Eucalyptus angulosa & $14.08 \mathrm{~d}^{*}$ & 51.73 \\
Lippia alba & $23.79 \mathrm{c}$ & 18.44 \\
Zingiber officinale & $25.07 \mathrm{c}$ & 14.05 \\
Cymbopagon citratus & $25.70 \mathrm{c}$ & 11.89 \\
Azadirachta indica & $26.46 \mathrm{~b}$ & 9.29 \\
Plectranthus barbathus & $26.68 \mathrm{~b}$ & 8.54 \\
Hibiscus sabdariffa & $26.73 \mathrm{~b}$ & 8.36 \\
Aloe vera & $26.78 \mathrm{~b}$ & 8.19 \\
Pedilanthus tithymaloides & $26.92 \mathrm{~b}$ & 7.71 \\
Mansoa alliacea & $27.46 \mathrm{~b}$ & 5.86 \\
Chenopodium ambrosioides & $27.63 \mathrm{~b}$ & 5.28 \\
Ocimum basilicum & $27.94 \mathrm{a}$ & 4.12 \\
Ocimum gratissimum & $28.16 \mathrm{a}$ & 3.46 \\
Morinda citrifolia & $28.50 \mathrm{a}$ & 2.30 \\
Control & $29.17 \mathrm{a}$ & - \\
\hline \multirow{}{*}{ Averages followed by same letter do no differ significantly each other by Scott-Knott test at 5\% probability }
\end{tabular}


Table 3. Effect of alcoholic extracts of medicinal plants on mycelial growth of Fusarium solani

\begin{tabular}{lll}
\hline Treatments & MGRI & Inhibition (\%) \\
\hline Eucalyptus angulosa & $15.37 \mathrm{~b}^{*}$ & 21.06 \\
Lippia alba & $18.48 \mathrm{a}$ & 5.08 \\
Aloe vera & $18.58 \mathrm{a}$ & 4.57 \\
Zingiber officinale & $19.12 \mathrm{a}$ & 1.80 \\
Cymbopagon citratus & $19.23 \mathrm{a}$ & 1.23 \\
Hibiscus sabdariffa & $19.26 \mathrm{a}$ & 1.08 \\
Pedilanthus tithymaloides & $19.37 \mathrm{a}$ & 0.51 \\
Control & $19.47 \mathrm{a}$ & - \\
Azadirachta indica & $19.62 \mathrm{a}$ & - \\
Morinda citrifolia & $20.10 \mathrm{a}$ & - \\
Chenopodium ambrosioides & $20.13 \mathrm{a}$ & - \\
Ocimum gratissimum & $20.44 \mathrm{a}$ & - \\
Mansoa alliacea & $20.50 \mathrm{a}$ & - \\
Plectranthus barbathus & $20.53 \mathrm{a}$ & - \\
Ocimum basilicum & $20.84 \mathrm{a}$ & - \\
\hline *Averages followed by same letter do no differ significantly each other by Scott-Knott test at 5\% probability
\end{tabular}

Table 4. Effect of alcoholic extracts of medicinal plants on mycelial growth of Rhizoctonia solani

\begin{tabular}{lll}
\hline Treatments & MGRI & Inhibition (\%) \\
\hline Eucalyptus angulosa & $32.79 \mathrm{f}^{\star}$ & 28.68 \\
Zingiber officinale & $39.92 \mathrm{e}$ & 13.18 \\
Lippia alba & $40.09 \mathrm{e}$ & 12.81 \\
Mansoa alliacea & $43.21 \mathrm{~d}$ & 6.02 \\
Plectranthus barbathus & $43.61 \mathrm{~d}$ & 5.15 \\
Control & $45.98 \mathrm{c}$ & - \\
Azadirachta indica & $46.64 \mathrm{c}$ & - \\
Cymbopagon citratus & $47.46 \mathrm{~b}$ & - \\
Ocimum gratissimum & $48.19 \mathrm{~b}$ & - \\
Aloe vera & $48.53 \mathrm{~b}$ & - \\
Pedilanthus tithymaloides & $48.73 \mathrm{~b}$ & - \\
Ocimum basilicum & $48.75 \mathrm{~b}$ & - \\
Morinda citrifolia & $49.84 \mathrm{a}$ & - \\
Chenopodium ambrosioides & $50.04 \mathrm{a}$ & - \\
Hibiscus sabdariffa & $50.21 \mathrm{a}$ & - \\
\hline${ }^{*}$ Averages followed by same letter do no differ significantly each other by Scott-Knott test at 5\% probability
\end{tabular}

the gallic acid from E. darlympleana methanol extract and it was found to be effective in mycelial growth and spore germination of Botrytis cinerea, the fungal pathogen causing kiwifruit soft rot decay during postharvest storage [17].

The activity of the extracts of $Z$. officinale and $L$. alba can also be highlighted. After the extract of $E$. angulosa, the extracts appeared to cause frequently the greatest inhibitions of the three studied fungi growth (C. gloeosporioides, F. oxysporum f. sp. passiflorae and $R$. solani).
Among the results presented, the extract of $Z$. officinale against $R$. solani showed higher results than those reported by Choudhury, et al. [18], who reported that $Z$. officinale hexane extract inhibited the growth of the pathogen by $9.26 \%$. Hedge, et al. [14] obtained superior results. The aqueous extract of $Z$. officinale at a concentration of $5 \%$ inhibited the growth of C. gloeosporioides by $39.99 \%$. As reported by Ferreira, et al. [19], the aqueous extract of $L$. alba at a $8 \%$ concentration inhibited of C. gloeosporioides growth by $41.9 \%$. 
These results provides important information for further isolation and characterization studies of active compounds of species $E$. angulosa, $Z$. officinale and $L$. alba, necessary for the development of biopesticides for the control de plant diseases caused by fungi.

\section{CONCLUSION}

According to the results, it can be inferred that alcoholic extracts of medicinal plants represent a viable and ecologically correct strategy in the management of plant diseases through the antimicrobial action that they can exert against pathogens. All extracts tested had an antimicrobial potential. The extract of $E$. angulosa reduced the mycelial growth of all evaluated fungi. Thus, the $E$. angulosa extract represents a potential alternative for the control of $P$. edulis diseases caused by phytopathogenic fungi.

\section{COMPETING INTERESTS}

Authors have declared that no competing interests exist.

\section{REFERENCES}

1. Ishida AKN, Halfeld-Vieira BA. Bacterial spot of passionfruit (Xanthomonas axonopodis pv. passiflorae): Etiology and control strategies. Bethlehem: Embrapa Eastern Amazon. Portuguese; 2009.

2. Santos Filho HP, Orange FF. Diseases caused by fungi. In: Lima AA, Cunha MAP, editors. Passionfruit: Production and quality in passiculture. Soul Cross: Embrapa Cassava and Fruit Portuguese; 2004.

3. Benato EA. Postharvest disease control in tropical fruit trees. Summa Phytopathol. Portuguese. 1999;25(1):90-3.

4. Ferreira RB, Rodrigues AAC, Moraes FHR, Silva EKC, Birth IO. Organic waste in the control of Fusarium oxysporum f. sp. passiflorae in yellow passionfruit (Passiflora edulis f. flavicarpa). Acta Biol Colomb. Portuguese. 2015;20(3):11120.

5. Poltronieri LS, Trinity DR, Albuquerque FC, Duarte MLR, Poltronieri MC. Passionfruit diseases in the state of Pará. Belém: Embrapa Eastern Amazon Portuguese; 2001.
6. Verzignassi JR, Poltronieri LS, Benchimol RL. Occurrence of Rhizoctonia solani AG1 in Emperor's staff in the state of Pará. Summa Phytopathol. Portuguese. 2008; 34(3):290.

7. Bettiol W. Biocontrol of plant diseases: Use and perspectives. Jaguariúna: Embrapa Environment. Portuguese; 2009.

8. Bettiol W. Biological control of plant diseases. Jaguariúna: Embrapa CNPDA. Portuguese; 1991.

9. Soares ACS. Botanical extracts for the control of pest insects and diseases in family farming. Federal University of Pará. Belém, Portuguese; 2010.

10. Biermann ACS. Bioactivity and botanical insecticides on Ascia monuste orseis (Lepdoptera: pieridae). Federal University of Santa Maria. Santa Maria. Portuguese; 2009.

11. Amorim EPR, Andrade FWR, Moraes SEM, Silva JC, Lima RS, We read EEP. Antibacterial activity of essential oils and plant extracts on the development of Ralstonia solanacearum in banana seedlings. Rev Bras Frutic. Portuguese. Special. 2011;392-8.

12. Oliveira JA. Effect of fungicide treatment on seeds in seedling control of cucumber (Cucumis sativas L.) and sweet pepper (Capsicum annanum L.) seedlings. Higher School Of Lavras Agriculture. Mining. Portuguese; 1991.

13. Scott A. Knott MA. Cluster-analysis method for grouping means in the analysis of variance. Biometrics. 1974;30(3):50712.

14. Hegde YR, Chavhan TL, Keshgond RS. Antifungal activity of plant extracts on Colletotrichum gloeosporioides infecting Jatropha curcas. The Bioscan. 2014;9(1): 283-6.

15. Koma B, Dewangan P, Baghel S, Dantre RK, Verma KP. Efficacy of plant leaf extracts on mycelia growth and sclerotial production of Rhizoctonia solani causing web blight of groundnut. Int J Plant Prot. 2014;7(1):272-4.

16. Singh IP, Sidana J. Chemistry of the Eucalyptus genus. IN: Bhojvaid PP, Kaushik S, Singh YP, Kumar D, Thapliyal M, Barthwal S, Editors. Eucalyptus in India. Dehradun: Envis Center on Forestry; 2014.

17. Oh SO, Kim JA, Jeon HS, Park JC, Koh YJ, Hur H, Hur JS. Antifungal activity of eucalyptus-derived phenolics against 
postharvest pathogens of kiwifruits. Plant Pathol J. 2008;24(3):322-7.

18. Choudhury D, Anand YR, Kundu S, Nath R, Kole RK, Saha J. Effect of plant extracts against sheath blight of rice caused by Rhizoctonia solani. J Pharmacogn Phytochem. 2017;6(4):399-404.
19. Ferreira EF, San Jose AR, Bomfim MP, Porto JS, Jesus JS. Use of plant extracts for in vitro control of Colletotrichum gloeosporioides penz. collected from papaya (Carica papaya L.) fruits. Rev Bras Frutic. Portuguese. 2014;36(2):34652.

(c) 2019 Silva et al.; This is an Open Access article distributed under the terms of the Creative Commons Attribution License (http://creativecommons.org/licenses/by/4.0), which permits unrestricted use, distribution, and reproduction in any medium, provided the original work is properly cited.

Peer-review history:

The peer review history for this paper can be accessed here: http://www.sdiarticle4.com/review-history/53424 